\title{
Lymphomatoid Granulomatosis in 10-Month-Old Infant with Lymphopenia: Case Report and Review of the Literature
}

\author{
Mehmet Akif OZDEMIR ${ }^{1}$, Yasemin A. TORUN ${ }^{1}$, Musa KARAKUKCU ${ }^{1}$, Olgun KONTAS ${ }^{2}$, \\ Turkan PATIROGLU ${ }^{1}$, Ali YIKILMAZ ${ }^{3}$ \\ ${ }^{1}$ Erciyes University Faculty of Medicine, Department of Pediatric Hematology \\ ${ }^{2}$ Erciyes University Faculty of Medicine, Department of Pathology \\ ${ }^{3}$ Erciyes University Faculty of Medicine, Department of Radiology, Kayseri, TURKEY
}

\begin{abstract}
Lymphomatoid granulomatosis (LYG) is an aggresive multiorgan disease that primarily affects the lung but may also involve extrapulmonary sites including the central nervous system, skin, and kidney. The incidence is the highest in middle-aged men and is rare in children. We report a case of LYG involving lung, liver, and skin in a 10-month-old infant who is the youngest patient in the literature.
\end{abstract}

Keywords: Infant, Lymphomatoid granulomatosis, Lymphopenia

ÖZET

Lenfopenisi olan 10 aylık bir infantta Lenfomatoid Granülomatozis

Lenfomatoid Granülomatozis (LYG) öncelikle akciğer olmak üzere santral sinir sistemi, deri ve böbreği içine alan extrapulmoner bölgelerde de görülebilen agresiv, bir çok organı tutan bir hastalıktır. Orta yaş erkeklerde sıklıkla görülürken çocuklarda nadirdir. Bu yazıda akciğer, karaciğer ve deri tutulumu olan literatürdeki en küçük yaşta hasta olarak 10 aylik bir infant rapor edilmiştir.

Anahtar Kelimeler: Infant, Lenfomatiod granülomatozis, Lenfopeni 


\section{INTRODUCTION}

Lymphomatoid granulomatosis (LYG), first described by Liebow et al. in 1972, was a rare malignant angiocentric, angiodestructive lymphoreticular proliferative disease that commonly affects the lungs. ${ }^{-}$ ${ }^{4}$ While LYG primarily affects the lung, other organs including skin, liver, central nervous system, and kidney can also be affected by LYG lesions.-5

Although most cases occur sporadically in otherwise immunocompetent patients, there are many reports of LYG including acquired and congenital immunodeficiency states, lymphoma (both Hodgkin's and non-Hodgkin's), rheumatoid arthritis, ulcerative colitis, tumors of the gastrointestinal tract and breast, infectious hepatitis, psoriasis, and sarcoidosis. ${ }^{6}$ The prognosis of the disease has been considered to be relatively poor with progression to malignant lymphoma in 13\%. ${ }^{4}$ Immunophenotype of LYG has been described as a T-cell rich, EbsteinBar virus (EBV)-associated, B-cell lymphoproliferative disorder. ${ }^{1-4,6}$

In this report, we describe a 10-month-old infant with LYG, who was diagnosed based on pathological findings and radiological imaging and possibly associated with primary EBV infection, which was progressed to malignant lymphoma.

\section{CASE REPORT}

A 10-month-old girl presented at our hospital with a history of $39^{\circ} \mathrm{C}$ temperature, cough, and dyspnea, beginning 20 days before admission. General physical examination revealed that a small child, below the 10th percentile for both height and weight (she was only fed with cow's milk. Her nutrition and hygiene were poor), was hypoxic on room air. Physical examination of chest showed wheezes with rare soft in the lobes bilaterally. We found a firm, well defined, round, and solid mass, 2 x $2 \mathrm{~cm}$ size on the right side of the jaw. The spleen and liver were palpable to $4 \mathrm{~cm}$ and $6 \mathrm{~cm}$ below the costal margin, respectively. Complete blood count result was as follows: hemoglobin, $9.6 \mathrm{~g} / \mathrm{dl}$; platelets, $402 \times 10^{9} / \mathrm{L}$; white blood cells, $8.5 \times 10^{9} / \mathrm{L}$ with $70 \%$ polys and $15 \%$ lymphocytes (absolute lymphocyte count $=1275 / \mathrm{mm}^{3}$ ). Bone marrow biopsy was normal. Immunoglobulin levels are normal. Liver and kidney function tests were normal.
Serology for the EBV was positive. The serology was confirmed by an outside laboratory. An extensive vasculitis workup and HIV test were negative. Laboratory tests are normal except the lymphopenia. A computerized tomography revealed diffuse, confluent bilateral pulmonary nodules (Figure 1). The patient was admitted to the pediatric intensive care unit and was started on IV antibiotics. Despite antibiotic treatment, the patient's fever increased and the patient started to desaturate.

Tissue sampling was recommended. A biopsy specimen from the skin nodule showed a highly atypical lymphoid infiltrates that displayed a prominent angiocentric and angiodestructive pattern of growth. Histopathologic examination showed extensive destruction and large necrosis area of nodule diffusely by a malignant lymphocytic infiltration that was $\mathrm{CD} 20, \mathrm{CD} 3, \mathrm{CD} 3$ epsilon positive but ALK, EMA, CD30, CD5, CD56 negative, larger than normal lymphocyte, atypical, a marked nucleolus, and concentrating around the blood vessels (Figure 2a, b, c). EBV LMP-1 immunostainning was strongly positive (Figure 2d). The histopathologic findings in most areas were consistent with grade III lesions were described a monomorphic infiltrate and marked cytological atypia in both small and large lymphoid cells..$^{-4}$ No yeast, fungi or acidfast bacilli were detected. Pathologic diagnosis was CD20 positive B-cell lymphoma with reactive Tcells.

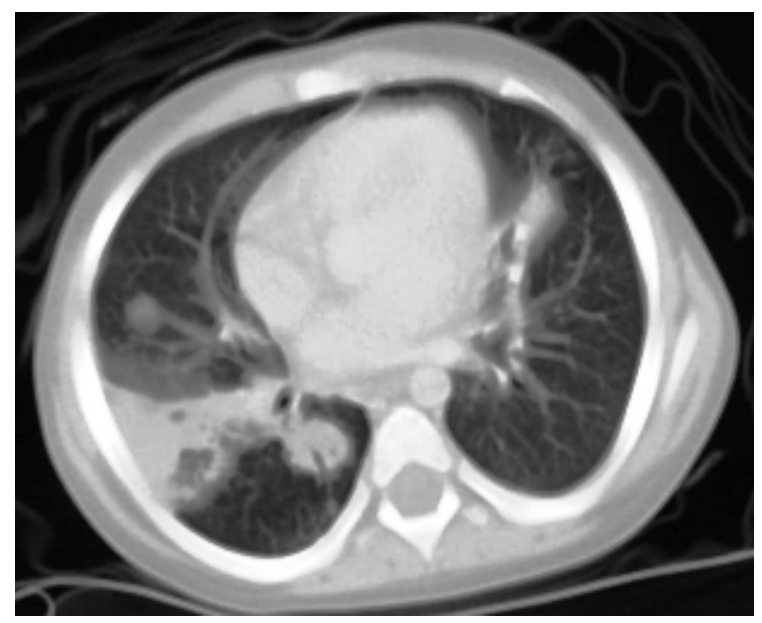

Figure 1. Bilateral noduler consolidation and cavitation in the lung 

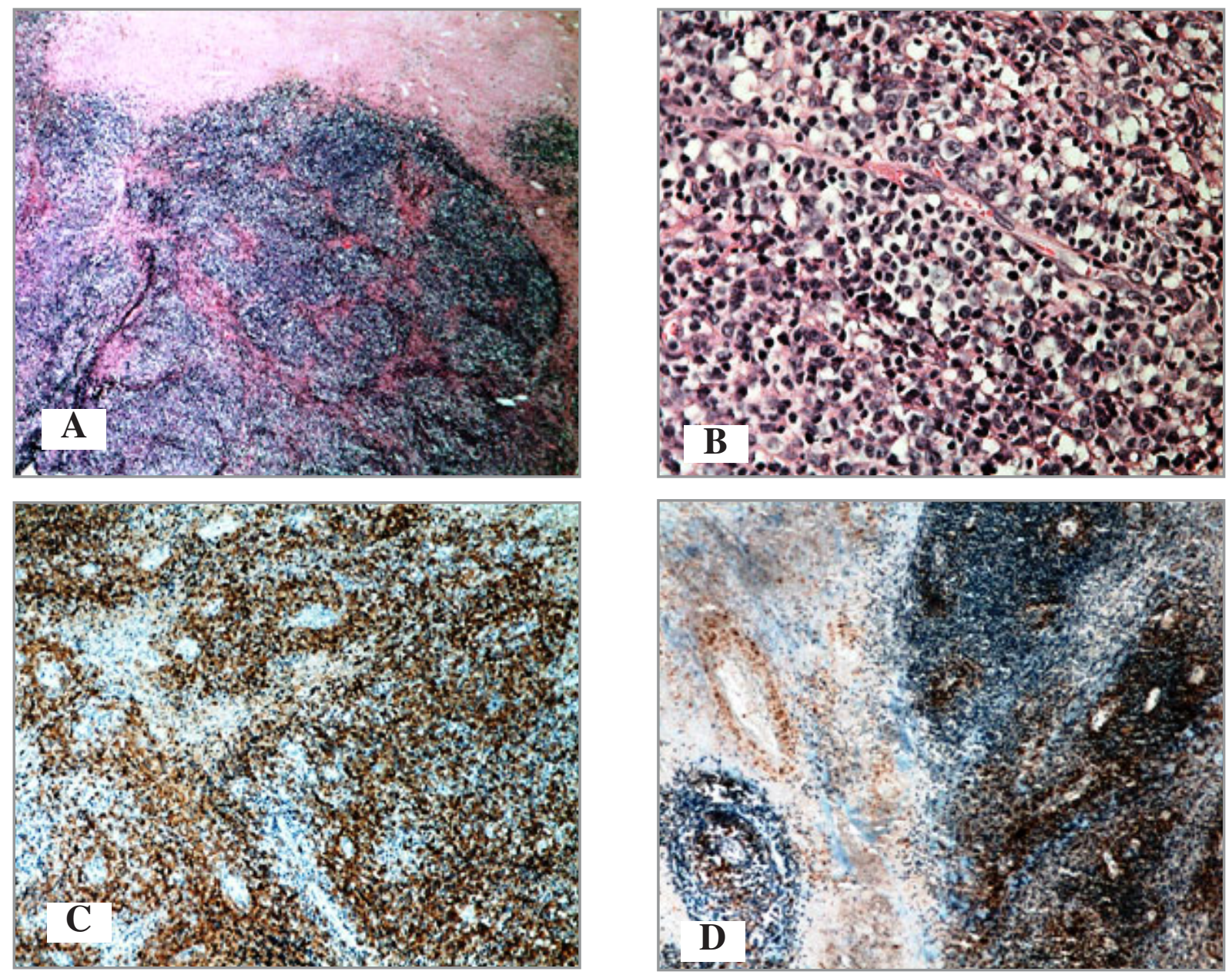

Figure 2. Diffuse lymphoid infiltration that have extensive necrosis area and pleomorphic perivascular infiltrate (A); lymphoid cell with marked nucleolus, angiocentric linage (B); CD2O immunostain with a membranous positivity of large tumor cells (C); and most cells are stained by LKM for EBV (D).

We treated with intensified CHOP (cyclophosphamide, doxorubicin, vincristine, and prednisone) and rituximab once a week. After the second cycle, a CT scan of the chest, liver and spleen showed progressive disease. The number as well as the size of the nodules had increased. She died 2 months after initial presentation from respiratory failure due to progressive disease.

\section{DISCUSSION}

LYG, an angiocentric necrotic EBV-related lymphoproliferative disorder, is only rarely described in children, with the literature mainly limited to case report. ${ }^{1-4}$ Katzenstein's series of 152 patients with LG included 12 patients under the age of 20.7 Although LG was defined as an angiodestructive lymphoproliferative and granulomatous disease involving predominately the lungs, it could frequently affect other organs such as nervous system $(67 \%)$, skin (39\%), kidney (32\%), spleen (18\%), liver $(12 \%)$, heart $(11 \%)$, and lymph nodes $(8 \%){ }^{3}$

It has long been recognised that immunocompromised patients are predisposed to develop LYG.1-4,8 The disease has been reported in patients with secondary as well as primary immunodeficiency. Moreover, many authors have pointed out the presence of biological immune disorders in LYG such as lymphopenia, anergy, decrease in the in vitro reactivity to mitogens and antigens or inversion of the T4/T8 ratio. ${ }^{8}$ Furthermore, lymphopenia without clinical manifestations of immunodepression was noted some reports. ${ }^{8}$ Therefore, LYG seems to rep- 
resent an EBV-related lymphoproliferation of the B-cell lineage preferentially arising in patients with immune disorders. An additional finding in our patient was a lymphopenia and considered to be a possible predisposition to LYG.

The typical histopathology is very important to the differential diagnosis between LYG and extranodal nasal natural killer (NK)/T-cell lymphoma. Extranodal nasal natural killer (NK)/T-cell lymphoma is a very rare lymphoma characterized by strong association with Epstein-Barr virus infection, very aggressive clinical behavior, and poor prognosis. The typical phenotype of neoplastic natural killer cells in this entity is as follows: CD2+, CD20-, surface CD3-, cytoplasmic CD3epsilon+, and cytotoxic granule-associated protein positive. Cellulitis and ulcer were the major cutaneous manifestations.9,10

Nichols et al. ${ }^{11}$ first postulated that LYG was a Tcell lymphoma because the majority of the lymphocytes were thought to be T-cells. Wilson et al. ${ }^{12}$ confirmed T-cell predominance but suggested that the process was dependent on an EBV-associated B-cell lymphoproliferative phenomenon. Furthermore these B-cells were demonstrated to have higher proliferation rates than T-cells in the same lesion. In most cases of LYG, the T-cells are not atypical or neoplastic, but are reactive. ${ }^{2}$

Three grades were described by Lipford et al, based on the degree of cytological atypia, extent of necrosis, and retention of a polymorphous cellular infiltrate. ${ }^{13,14}$ Grade I is difficult to diagnose on histological examination, as only scattered tumor cells are present, dispersed in an abundant population of non-atypical $\mathrm{T}$ cells. One third of grade I lesions will progress to malignant lymphoma. The main differential diagnosis at this stage is vasculitis. Grade II lesions are polymorphous with atypical cells and foci of necrosis, as in most cases of LYG. Most cases have been shown to be EBV related. Grade III lesions morphologically resemble high-grade malignant lymphoid neoplasm. ${ }^{1,15}$ Prognosis depends on the lymphocyte proliferation, immunoblasts, necrosis area, and cytological atypia. ${ }^{1}$

This lymphoproliferative disorder is aggressive and difficult to diagnose; many of the reported cases have been diagnosed after death. ${ }^{16}$
Although initially it has been thought to be a nonneoplastic lesion, progression or transformation to malignant lymphoma has been noted in $12-47 \%$ of the patients. ${ }^{2}$

The skin is the second common extrapulmonary site of LYG, with cutaneous lesions arising in 39$51 \%$ of patients. ${ }^{2}$ Biopsy of cutaneous lesions of LYG may spare the patient a more invasive procedure such as open lung biopsy.

The optimal therapy of LYG has been controversial. There is no standard treatment, but promising results have been reported with rituximab, either as monotherapy or in combination with chemotherapy. ${ }^{16} \mathrm{~A}$ combination of radiotherapy and chemotherapy, allogenic bone marrow transplantation, and interferon-alfa $2 \mathrm{~b}$ treatments are reported to induce successful results. But mortality varied from 64 to $69 \%$ and durable complete remission ranged from 24 to $27 \%$. This mortality rate shows that LYG is still a chemotherapy-resistant disease in grade III patients despite the addition of rituximab. ${ }^{1,17}$

In conclusion, this case illustrates that LYG is difficult to diagnose clinically and may be seen also in the pediatric age range. One should keep this in mind as a possible diagnosis for antibiotic-resistant pneumonitis, with characteristic radiological features, clinical course, and evidence of EBV infection especially in patients with lymphopenia.

\section{REFERENCES}

1. Mazzie JP, Price AP, Khullar P, et al. Lymphomatoid granulomatosis in a pediatric patient. Clin Imaging 28: 209-313, 2004.

2. LeSueur BW, Ellsworth L, Bangert JL, Hansen RC. Lymphomatoid granulomatosis in a 4-year-old boy. Pediatr Dermatol 17: 369-372, 2000.

3. Moertel CL, Carlson-Green B, Watterson J, Simonton SC. Lymphomatoid granulomatosis after childhood acute lymphoblastic leukemia: report of effective therapy. Pediatrics 107: 82, 2001.

4. Nishihara $\mathrm{H}$, Tateishi $\mathrm{U}$, Itoh $\mathrm{T}$, et al. Immunohistochemical and gene rearrangement studies of central nervous system lymphomatoid granulomatosis. Neuropathology 27: 413-418, 2007.

5. Karnak I, Ciftci AO, Talim B, et al. Pulmonary lymphomatoid granulomatosis in a 4 year old. J Pediatr Surg 34: 1033-1035, 1999. 
6. Fassas A, Jagannath S, Desikan KR, et al. Lymphomatoid granulomatosis following autologous stem cell transplantation. Bone Marrow Transplant 23: 79-81, 1999.

7. Katzenstein AL, Carrington CB, Liebow AA. Lymphomatoid granulomatosis: a clinicopathologic study of 152 cases. Cancer 43: 360-373, 1979.

8. Tanière $P$, Thivolet-Béjui $F$, Vitrey $D$, et al. Lymphomatoid granulomatosis- a report on four cases: Evidence for B phenotype of the tumoral cells. Eur Respir J 12: 102-106, 1998.

9. Ferenczi $\mathrm{K}$, Summers $\mathrm{P}$, Aubert $\mathrm{P}$, et al. A case of CD30+ nasal natural killer/T-cell lymphoma. Am J Dermatopathol 30: 567-571, 2008.

10. Suzuki R, Takeuchi K, Ohshima K, Nakamura S. Extranodal NK/T-cell lymphoma: diagnosis and treatment cues. Hematol Oncol 26: 66-72, 2008.

11. Nichols PW, Koss M, Levine AM, Lukes RJ. Lymphomatoid granulomatosis: A T-cell disorder? Am J Med 72: 467-471, 1982.

12. Wilson $\mathrm{WH}$, Kingma DW, Raffeld $\mathrm{M}$, et al. Association of lymphomatoid granulomatosis with Epstein-Barr viral infection of $\mathrm{B}$ lymphocytes and response to interferon-alpha 2b. Blood 87: 4531-4537, 1996.

13. Lipford EH Jr, Margolick JB, Longo DL, et al. Angiocentric immunoproliferative lesions: a clinicopathologic spectrum of post-thymic T-cell proliferations. Blood 72: 1674-1681, 1988.

14. Harris NL, Jaffe ES, Diebold J, et al. The World Health Organization classification of neoplasms of the hematopoietic and lymphoid tissues: report of the Clinical Advisory Committee meeting - Airlie House, Virginia, November, 1997. Hematol J 1: 53-66, 2000.
15. Salmons N, Gregg RJ, Pallalau A, et al. Lymphomatoid granulomatosis in a patient previously diagnosed with a gastrointestinal stromal tumour and treated with imatinib. J Clin Pathol 60: 199-201, 2007.

16. Jaffre $S$, Jardin F, Dominique $S$, et al. Fatal haemoptysis in a case of lymphomatoid granulomatosis treated with rituximab. Eur Respir J 27: 644-646, 2006.

17. Oosting-Lenstra SF, van Marwijk Kooy M. Failure of $\mathrm{CHOP}$ with rituximab for lymphomatoid granulomatosis. Neth J Med 65: 442-427, 2007.

\section{Correspondence}

Dr. Yasemin Altuner TORUN

Erciyes Üniversitesi Tip Fakültesi

Pediatrik Hematoloji Bilim Dalı

Talas Caddesi

38039 Kayseri / TURKEY

Tel: (+90.352) 2357732

Fax: (+90.352) 4375825

E-mail: yaseminaltuner@yahoo.com 